\title{
Could Certification on Sustainable Tourism Result in Destination Loyalty?
}

\author{
Diena Mutiara Lemy and Amelda Pramezwary \\ Hospitality Management \\ Universitas Pelita Harapan - School of Hospitality and Tourism \\ Tangerang, Banten - Indonesia \\ diena.lemy@uph.edu
}

\begin{abstract}
The purpose of this study is to conceptualize a model of sustainable tourism development certification in a destination which can result on destination loyalty and to find out whether the accountability of the destination in turning the certification standards tangible to the tourists can create positive experience during their stay and may enhance the positive image of the destination in the visitors' mind and finally resulted on destination loyalty. The conceptual model was developed on the basis of existing theoretical and empirical research in the fields of marketing and tourism. The model includes five constructs, with destination loyalty being the outcome. The result of a continuous tourist satisfaction monitoring guaranteed through sustainable tourism development certification could be serve as an input for destination loyalty and strategic discussions. It can help the development of a tourist destination by identifying strategic objectives at the destination level, preparing tactical and operational plans and ultimately increasing the competitiveness of a given destination. Achieving tourists' intention to revisit and recommend others would be one of the most important goals for destination loyalty, to our knowledge, only a few universal cause-and-effect measurement instruments/models have been developed to support this goal, one of them is through certification.
\end{abstract}

Keywords-Sustainable tourism, destination loyalty, sustainable tourism certification

\section{INTRODUCTION}

Tourism industry has been growing rapidly during the last half century. In 2015, The Ministry of Tourism of Indonesia noted that in tourism sector there is an ever increasing number of destination worldwide opened, invest, and turning tourism into key of export revenues, jobs creator, enterprises and infrastructure development. In addition to that, tourism has also experienced continued expansion and diversification, becoming one of the largest and fastest-growing economic sectors in the world.

Data from UNWTO Tourism Highlights (2014), UNWTO World Tourism Barometer (2015) and WTTC (2015) reveals that despites occasional shocks, international tourist arrival have shown virtually uninterrupted growth, from 25 million in 1950 to 278 million in 1980 and 528 Million in 1995. The peak is in 2014 where the number of international tourist arrival has reached 1,138 million. On the side of domestic tourist arrival, tourism also notes the number of 5 to 6 billion domestic tourists in the world.
Some facts regarding tourism as the leading sectors according to UNWTO Tourism Highlights (2014), UNWTO World Tourism Barometer (2015) and WTTC (2015) are as follows:

- $\quad$ Tourism has booked $9.5 \%$ of GDP - Direct, Indirect and Induced Impact (2014)

- Tourism also contributes 1 in 11 jobs in the world

- Tourism reached $5 \%$ of the world's export with the value of US\$ 1.4 Trillion

However, there is another side of the story of tourism flying colors achievement that have to be paid attention to. The increasing tourism activities that invites a big number of tourists from may destroy the very thing that motivate them to come to a destination, especially if the tourism destination is located in a developing country. Rattan (2015) stated that all kinds of tourism, whether mass or alternative, are by definition incapable of being completely sustainable, as they almost always involve the use of environmentally unfriendly methods of transportation. The carbon footprint left by tourists travelling by plane to and from destinations has damaging effects on the environment of the home and host countries. Therefore, a movement to safe tourism from destroying the environment, society and culture should be taken, and it comes in the form of sustainable tourism.

The concept of sustainable tourism would need support and contribution from the people who live around the destination because they play the major part in the development. The residents are the ones who will be suffered from the negative impact and at the same time will get the benefits from the tourism activities. It is very important to make them believe, grasp the concept and finally contribute in the process.

Not only the local residents, the tourists' participation are also very important as the critical factor of sustainable tourism application in a destination. The attitude and behaviors of the visitors have a great impact on the existing tourism system. The way they interpret and accept the concept would be a driver for the related destination in consistently applied it. Therefore the destination has to take a step that is tangible for tourists. One alternative regarding the tangible action is through certification. According to Honey (2002:4) certification is a procedure that audits and gives written assurance that a facility, product, process, service, or management system meets specific standards. Thus, a 
certification can give a guarantee to the tourists on the quality of the destination. If the tourists satisfied then the destination may expect loyalty from them.

This paper is intended to explore the possibility of the sustainable tourism certification of a destination in affecting the tourist loyalty.

\section{SustainABLE TOURISM}

The concept of sustainable development is an alternative for economic and social development in tourism as a mechanism to conserve natural and cultural resources. This concept gets along well with the global issues that are related with the environmental quality and quality of life. The consequence of this approach is that all stakeholders in tourism business must change their paradigm in doing business. They must take into accounts that tourism is a sector that relates with so many aspects and sectors with both positive and negative impacts. Thus, a well-planned and careful development that has considered all related aspects must be done. The other important thing is that the development of tourism must be visionary and future anticipating. Dávid, (2011) stated that in the long run, a sustainable development in tourism has to be ecologically durable, economically executable, and at the same time socially and ethically fair in relation to the local population.

On the other side, this concept should not ignore the tourist as the consumer. It means the sustainable tourism development must take care the level of tourist satisfaction in a destination. This can happen through the enhancement of the quality of the environment and the more prepared local communities in a tourist destination. These two may affect the value and experience for the tourist which is important for satisfaction.

The objectives of sustainable tourism is to ensure that the existing tourism development at the present time could satisfy the demand of the tourist and the local residents (in terms of benefits they can obtain from tourism sector), but at the same time this development will also guarantee that the future need is well anticipated. Dávid (2011) suggested to achieve these objectives, there are some aspects that has to be considered:

a. Tourism has to be integrated in the planning

b. The local economy has to be supported

c. The local communities has to be involved in the planning process

d. Communication between shareholders and community

e. The local resources capacity building

f. Tourism marketing with focus on responsible tourism activities

g. Integrate the tourism policy in the general politics of local society

These considerations could be the critical factors in the application of sustainable tourism development. These considerations also can be guidelines for all stakeholders in the destinations in applying sustainable tourism development.
According to Ritchie \& Crouch (2004) in order to achieve sustainability there are four pillars of sustainability tourism that have to be embraced. The four pillars are:

\section{A. Ecological Sustainability}

Ecological sustainability is very important because most of attraction in a tourism destination lies on the beauty of the environment. On the other hand if the carrying capacity of the destination is exceeded because of the massive visitors, the local residents will be at stake. Therefore, preservation and conservation of the environment has to be put as priority.

TABLE I. ISSUES IN SUSTAINABLE TOURISM RESEARCH AND PRACTICE

\begin{tabular}{|c|c|c|c|c|}
\hline Issue & Fields and topics & $\begin{array}{l}\text { Practical } \\
\text { interest }\end{array}$ & $\begin{array}{l}\text { Research } \\
\text { progress }\end{array}$ & $\begin{array}{l}\text { Research } \\
\text { priority }\end{array}$ \\
\hline \multicolumn{5}{|l|}{ IMPACTS (+ E -) } \\
\hline $\begin{array}{l}\text { Site-scale, social \& } \\
\text { ecological }\end{array}$ & $\begin{array}{l}\text { Park management, recreation } \\
\text { ecology, cultural and } \\
\text { community change }\end{array}$ & Med & High & $* *$ \\
\hline Land-use change & $\begin{array}{l}\text { Parks politics, conservation } \\
\text { agreements, private and } \\
\text { community reserves }\end{array}$ & High & Low & *** \\
\hline \multicolumn{5}{|l|}{$\begin{array}{l}\text { Resource } \\
\text { consumption: }\end{array}$} \\
\hline general & Energy and water conservation & High & Med & $*$ \\
\hline specific & $\begin{array}{l}\text { Rare species used for souvenirs } \\
\text { etc }\end{array}$ & Low & Low & ** \\
\hline $\begin{array}{r}\text { Wastes and } \\
\text { pollution }\end{array}$ & Water chemistry, microbiology & Med & Med & ** \\
\hline Climate change & Climatology, climate impacts & Med & Low & ** \\
\hline \multicolumn{5}{|l|}{ RESPONSES } \\
\hline Individual & $\begin{array}{l}\text { Cultural contexts, values, } \\
\text { behaviours, responsibility }\end{array}$ & High & Low & *** \\
\hline Social, government & $\begin{array}{l}\text { Policy, planning, EIA, } \\
\text { legislation }\end{array}$ & Med & Med & ** \\
\hline Social, corporate & $\begin{array}{l}\text { Self-regulation, certification, } \\
\text { (de)marketing }\end{array}$ & High & High & * \\
\hline Technological & $\begin{array}{l}\text { Energy, water, materials } \\
\text { conservation, waste } \\
\text { treatment, recycling }\end{array}$ & High & High & * \\
\hline \multicolumn{5}{|l|}{ INDICATORS } \\
\hline Economic & Regional economies, poverty & High & High & * \\
\hline Social & Net gains, equity, welfare & High & High & $\begin{array}{l}* * \\
* * *\end{array}$ \\
\hline Environmental & $\begin{array}{l}\text { Lack of data, } \\
\text { incommensurable } \\
\text { parameters }\end{array}$ & High & Low & \\
\hline $\begin{array}{l}\text { Sustainability } \\
\text { (combined) }\end{array}$ & $\begin{array}{l}\text { Scope and definitions, } \\
\text { incommensurable } \\
\text { parameters }\end{array}$ & Low & Low & ** \\
\hline
\end{tabular}

Research priorities: *, lowest; ***, highest. Priorities reflect degree of prior research effort as well as significance of topic for sustainable tourism.

a. Source: Buckley (2012)

\section{B. Economic Sustainability}

One main benefit from tourism development in a destination is the economic benefit for the stakeholders which at the end will also become the benefit for the country. When we discuss about sustainability, economic is one important aspect because it would be a strong motivation for the stakeholders. Some considerations to achieve economic sustainability are multiple benefits from tourism activities, the utilization of local labor; job security for the local residents; the raise wages, salaries and benefits level in the related destination. 


\section{Sociocultural Sustainability}

Sociocultural sustainability is related to the health and vitality of social and cultural systems that considered meaningful by the community in their life. This terminology is also related to the quality of life that would be achieved if a sustainable tourism development is applied.

\section{Political Sustainability}

Political sustainability is one influential aspect in sustainability because policies in a country will be highly influenced by the political situation. Through politics, policies regarding ecology, economy and sociocultural would be built. Therefore, a sustainability of politics also becomes one pillar in sustainable development.

As a respond to the need of an alternate of the mass tourism that grows rapidly, many initiatives has been taken by countries and related experts all over the world. Howie (2003:4) compiled a short chronology of influential writings regarding contemporary perspective on sustainability:

a. 1972. The Limits to Growth: A Report for the Club of Rome

b. 1974. The World Conservation Strategy. International Union for Conservation of Nature and Natural Resources (IUCN).

c. 1987. Our Common Future. World Commission on Environment and Development (WCED).

d. 1992 United Nations Conference on The Environment and Development (UNCED), Rio de Janeiro, Brazil ('The Earth Summit').

Buckley (2012) also makes a compilation on some research and practice regarding Sustainable tourism. The compiled items are as in Tabel 1.

Besides some publications, there are also conference and seminar being conducted with sustainability as the main issues. Howie (2003: 2) and Bowman, (2011) noted that in 1992 United Nations Conference on the Environment and Development (UNCED) was held in Rio de Janeiro, Brazil. This event is popular with the name of Rio Conference. The Rio Conference was attended by most of world's leaders and resulted on a broader perspective of development which is known as sustainable development. Sustainable development will integrate economic with environmental and social objectives.

Further on, Bowman (2011) also put on the first World Conference on Sustainable Tourism in 1995 as a pillar for the world's awareness on sustainable development issues. He believes that this initiative has been a motivation that started in the late 1990's for the interest of some government and international organizations in regulating the tourist industry and educating both hosts and participants. The stakeholders and suppliers in a destination have been directed to be more aware on sustainability issues and apply it in their products in order to protect the environment.

The most current important event that related to sustainability issues is an event conducted by UNFCCC
(United Nation Framework Convention on Climate Change). The 2015 Paris Agreement, adopted in Paris on 12 December 2015 , marks the latest step in the evolution of the UN climate change regime and builds on the work undertaken under the Convention. The Paris Agreement charts a new course in the global effort to combat climate change. The Paris Agreement seeks to accelerate and intensify the actions and investment needed for a sustainable low carbon future. Its central aim is to strengthen the global response to the threat of climate change by keeping a global temperature rise this century well below 2 degrees Celsius above pre-industrial levels and to pursue efforts to limit the temperature increase even further to 1.5 degrees Celsius. The Agreement also aims to strengthen the ability of countries to deal with the impacts of climate change.

Even though the issues is more on the global climate change topic specifically on how to accelerate and intensify the actions and investment needed for a sustainable low carbon future, it is very relevant with sustainable development issues.

All of the events, researches and publications above are showing that the sustainable tourism has been one of an important topic for the world because it embraces aspects regarding the sustainability of our world. Therefore, a serious move to apply it should be started immediately.

According to Liu (2003), the concept of sustainability has been discussed widely as a strategy to overcome the negative impacts of tourism and maintain its long-term viability. This statement aligns with David (2011) that there are three key components to sustainability: economic, social and environmental. An effort to balance the three components can be considered as a movement to attain sustainability.

A change of paradigm in measuring success is also different between conventional tourism and sustainable tourism. In conventional tourism, success is measured through type of travel, number of visitors and how much money is spent. Meanwhile, sustainable tourism is measuring quality of travel, length of stay and how is the money spent. So it is clear that in sustainable tourism success is measured by deeper indicators.

However, the road towards sustainable tourism is not easy and not obstacle free, since the topic about sustainable tourism requires both the sustainable growth of tourism's contribution to the economy and society and the sustainable use of resource and environment (Liu, 2003). In addition, Liu (2003) also stated that without a good coordination and planning on tourism demand and supply, the two expected outcomes would never be achieved.

Challenges in applying sustainable tourism concept could come from these factors:

a. Lack of understanding on sustainable tourism concept This might happened when the socialization about the sustainable tourism concept was not enough, in terms of frequency and periodically. The promoters of this idea should explain the "what, why, who, when, where and how" of sustainable tourism in such a way that could make the related parties understand. The effect of this situation might come in two ways: they will reject the concept or 
they might accept it but will face many problems during the implementation.

b. The myopic view of the stakeholders that made them does not want to apply the concept

This situation might occur when there is no change of paradigm from the stakeholders in regards of tourism development. One example is if the actors from tourism business sectors do not want to apply the concept because the direct benefits from sustainable tourism will take a long time to happen. Or, on their opinion sustainable tourism practice is too complicated and will cause the more work to do.

c. The destination is not ready to apply the sustainable development concept.

After the explanation of the concept, the destination will do a self- assessment to determine whether they want to apply it or reject it. It is true that sustainable tourism development concept consists of so many aspects that demand a commitment from a destination to go along with it. Usually, the readiness of a destination becomes their reason to reject the idea.

To address the challenges, participation from the stakeholders in the destination is highly needed. Every person, group, entity, private business or government that may affect or affected by tourism development in an area can be considered as tourism stakeholders. Some examples of tourism stakeholders are: the local communities, the business entities and the government in the respected destination.

Byrd (2007) compiled some research regarding what important issues that may be assists by the involvement of the stakeholders:

a. Avoiding the misperception from the stakeholders that the decision regarding sustainable development are made top down, so it does not reflecting the needs and interests of the stakeholders.

b. To make the decision making process more transparent and not competing interests within itself (Beierle \& Konisky, 2000)

c. To avoid major conflicts that may arise from the stakeholder groups (Healey, 1998).

Furthermore, in his study, Byrd (2007) suggests that there is four distinct group that can be identified as stakeholders in sustainable tourism destination:

a. The present visitors

The present visitors are any individual or groups that currently are considered as the tourist in a destination and have impacts on local economy from their visit. The economic impact is resulted from their consumption on the tourism products in the respective destination. The present visitor can be considered as the stakeholders because they have interest in the related destination, and any changes on it may turns into positive or negative experience for them.

\section{b. The future visitors}

The future visitors are any individual or groups that have a great intention to visit a destination after they learned about it through some marketing exposures regarding the destination and also from the present visitors. The interest of the future visitors is highly related to what is currently or what are going to be existed in the destination. This situation must take into account by the tourism planners because it will affect their decision whether they are going to make their intention to visit an actual one.

\section{c. The present host communities}

What is referred, as the present host communities are all parties that currently make the host community. This group may consist of the local residents, business owners and government officials. The present host communities are very important because they are the group that have been stayed for a long time period in the respective destination and need to be assured that the resources in their environment is sufficient. The difficult thing is it is hard to define a single generic interest from the host communities because each group will have their own interest. However, it is inevitable that the support from this group will influence the success of the sustainable tourism development.

\section{d. The future host communities}

This stakeholders group can be describe as the individuals and groups that will become residents, business owners or governmental officials in the respective destination in the future. The may become the host communities because they move in or they were born in the community. The changes in the destination where the community exist will affect their decision. For those who may become residents from the movement process may reconsider their decision to move if the change is not align with their expectation. While for the future host communities who were born in it, the change may affect their decision to stay in their communities or leave. Therefore, the sustainable tourism development planners must include this group as the important stakeholder in their planning.

\section{Sustainable Tourism CeRTIFICATION}

According to Honey (2002) certification is a procedure that audits and gives written assurance that a facility, product, process, service, or management system meets specific standards. This is like a guarantee given to the customers that their expectation will be fulfilled.

In tourism sector, certification is intended to promote the concept and practice of sustainable tourism amongst the tourism stakeholders. On his research, Bowman, (2011) stated that as the tourism stakeholders started to be more focus on sustainability, efforts to conceptualize, measure and standardize sustainable tourism practice has been made.

Various stakeholders have performed these efforts over the years (Rattan, 2015). According to him the aim of these movements is to make tourism product that is more socially and environmentally friendly and create experience which:

a. To establish a range of standards in tourism industry

b. To initiate a responsible tourism practices, that is related to the use of social, cultural and environmental aspects of a destination.

c. To inform the tourists about the availability of sustainable tourism choices within a destination (Honey, 2002) 
Having said that, certification can be considered as something that can give benefits to the tourism sectors. These benefits compiled by Font (2002), Bowman (2011) and Rattan (2015):

a. Certification has been regarded as a source of competitive advantage that allows a small number of firms to stand out from the average.

b. Moreover, it is also a valid instrument to gather local stakeholders around the common purpose in defining standards to improve the contribution of tourism sustainable development.

c. Certification also valid to develop structures to encourage and support improvement of business units, working to a standard that will give them peer recognition, staff morale, eco-savings, peace of mind from beyond legislation compliance, that will make a firm more competitive in the medium term.

d. Assist the destination to comply with the standards which may lead to efficiency and cost reduction. In addition, it can be a marketing tool for the destination in building their image and branding, because by following certification standards of sustainable tourism the related destination has given their commitment to practice sustainability.

e. Give more advantages to the customers in having better service quality as well as information about the products and services they have paid.

f. Development and implementation of sustainable tourism certification in a developing country is a process that can result in an important dialogue and policy-making process about the type or tourism development that the country wishes to pursue.

g. Development and implementation of sustainable tourism certification in a developing country will also raise greater awareness in the business community of the needs and contributions of the local communities.

h. Development and implementation of sustainable tourism certification in a developing country would also shift some attitudes across sectors and generations.

i. The certification will raise an awareness of the importance of the state capacity (the ability of the government to develop and successfully implement effective policies). Best certification program might not result in the best outcome without sufficient existing state capacity.

The compiled benefits reveal that certification of sustainable tourism would give benefits not only for the destination, but also at the same time the business sectors and the tourists.

There are always two sides of the story. As there is many benefits may be obtained from sustainable tourism certification, the disadvantages also exist. Rattan (2015) makes notes on some researches that notify the weaknesses of certification scheme. The notes are: a. Too many certification and eco-labeling may create confusion on the consumers regarding the meaning and distinction between products (Miller, 2001)

b. Failure to apply what have been claimed as 'green' products or 'eco-friendly' will raise distrust from the consumers (D’Souza, 2004; Ellison, 2008)

c. Certification that managed and coordinated by transnational corporations has a tendency to focus on the advantage of the enterprise. Therefore, these kind of program need to be consistently monitored (Sasidharan, Sirakaya, \& Kerstetter, 2002).

d. The certification schemes are viewed as disadvantage by Small and Medium Enterprises since on their point of view, the certification is impractical and not attainable (Mycoo, 2006; Rivera \& Leon, 2005)

e. It is often that after being certified, there is little or no follow up to determine whether the certified entity is hold on to the standards and make improvement on it (Font, 2002). This situation causes a need of another monitoring institution to ensure the consistency.

The explanation above gives us something to reflect on when we are choosing a certification standard According to Font (2002), there are five aspects to analyze the feasibility of certification as an instrument for sustainability: equity, effectiveness, efficiency, credibility and integration.

a. Equity

Equity refers to the fairness of an instrument which is more on the accessibility of the certification for the tourism firms. The accessibility includes the cost of the certification program. If the cost is very high and many small firms in tourism industry could not afford it, then the certification program is considered as inequity.

b. Effectiveness

Effectiveness refers to the measure of how well an instrument achieved its objectives. For example, the power of a company with ecolabels to change the behavior in other companies towards sustainability. Effectiveness can also be measured as how far the agenda of sustainability has been achieved. For example, even though it is still being argued, an agreement from local groups to apply the practical methods to make local firms more sustainable can be considered as an achievement.

c. Efficiency

Efficiency is a measure of how well an instrument uses the available resources. In most countries that has applied certification, certification program mostly rely on external funding (grant or government subsidiary). However, the effectiveness of the certification program cannot be measured immediately since voluntarily changing industry behavior is a long-term process.

d. Credibility and Legitimation

Credibility and legitimation refer to the extent up to which an instrument is accepted as valid by its target audience.

e. Integration 
Integration refers to the ability of the certification instrument with other instruments for sustainability. So far, generally certification is only integrated with other instruments for sustainability only in as far as they are generally linked to voluntary initiatives and incentives to encourage a more sustainable approach to management.

\section{DESTINATION LOYALTY}

Loyalty can be defined as an observable behavior of the customer towards a certain brand, service or product through repeat patronage behavior (Dick \& Basu, 1994). Camarero (2007) stated that loyalty is a result from activities that involved customer interaction and repurchase behavior. Nowadays, customer loyalty plays an important role both in neither products nor services. This is mainly because the customer loyalty and retention brings positively affecting the company's profit (Zineldin, 2006). In other words, if a company obtain the loyalty from the customers it may as well experience growth.

Research of Rundle-Thiele (2005), suggest that dimensions of loyalty may include propensity to be loyal, behavioral intentions, complaining behavior, resistance to competing offers, attitudinal loyalty and behavioral loyalty. Thus, when we discuss about loyalty, we should see it as a multidimensional variable and must be understood by the marketers in order to achieve the marketing objectives.

These perceptions regarding loyalty give an insight on how to measure the concept. Directly, it can be measured through repeating buying behavior, the use of the related product or services for a certain period of time and also the tendency to choose a certain brand compare to other brands that offer the same of product or services. Indirectly, the concept of loyalty can be measured through the willingness of the customers to recommend the product of services to others.

Customer Loyalty may give various benefits which are include financial benefits, marketing benefits, and communication benefits. A composite measure is proposed, which integrates behavior and attitude, considering that the customer must have positive attitude and behavior towards a hotel for it to be considered true loyalty (Bowen \& Chen, 2001).

In measuring the loyalty of a tourist toward a destination, loyalty can be measured through behavior, by considering repeat purchasing. This is similar with the general loyalty measurement. Study by Hernández-Lobato, Solis-Radilla, Moliner-Tena, \& Sánchez-García, (2006) confirm the strong relationship among the perceived quality or the cognitive image service quality, satisfaction and the intention of loyalty. This study also empirically stating the importance of the emotions behind the people's intention to return to a tourist destination.

Gursoy, Chen, \& Chi (2014) have made a conceptual review on tourist destination loyalty and proposed a conceptual model called Destination Loyalty Formation (DLF).

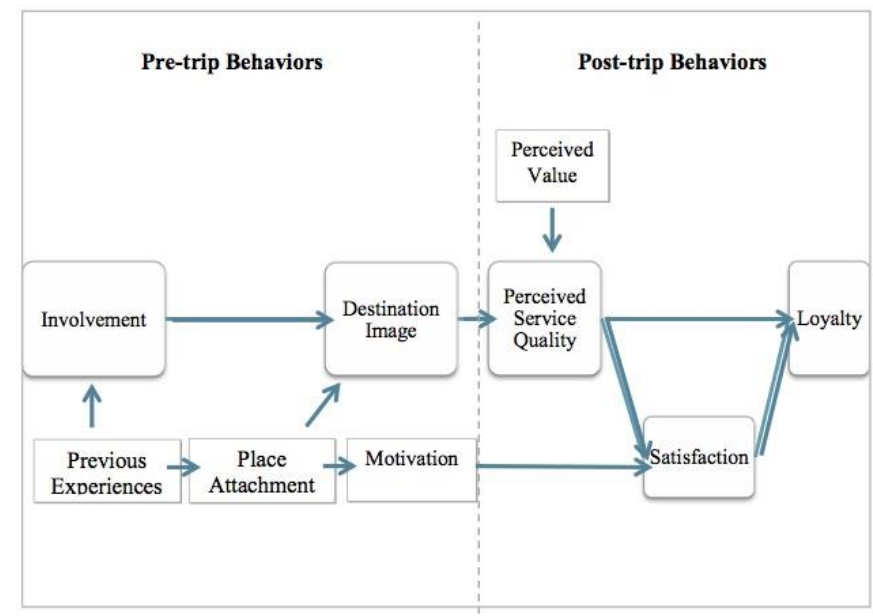

Fig. 1. DLF MODEL Source: Gursoy et al., (2014)

The model describing these relationships: First, there is a sequential relationships among antecedents of tourist destination loyalty where previous visit is the most significant driver that could manipulate tourist destination loyalty. Second, place attachment and involvement constitute the second most influential factor of DLF. Third, destination image affects perceived service quality and satisfaction directly and indirectly.

This is in line with the study by Kandampully and Suhartanto (2000) which found that customer satisfaction and image towards the service provider have an impact on the loyalty. Thus, it is important for a service provider to satisfied their customer and build a good image. Fourth, both perceived service quality and satisfaction are proposed to have a large direct impacts on destination loyalty.

Namely, tourist loyalty to the products or destination may not be enough to explain why and how they are willing to revisit or recommend these to other potential tourists.

In this study, the definition of loyalty refers to (Yoon \& Uysal, 2005) where loyalty is defined as tourists' intention to revisit and their recommendation to others and has a causal relationship with motivation and satisfaction. Thus, the reviewed literature suggests that a full understanding of loyalty need to consider both motivation and satisfaction constructs simultaneously.

\section{RESUlT AND DISCUSSION}

It has been discussed earlier that tourism industry has grown very rapidly and give various benefits to the related countries. However, the vast development need to be assessed and monitored carefully since tourism activities can cause neither positive nor negative impact to the communities. The increasing tourism activities that invite a big number of tourists from may destroy the very things that motivate them to come to a destination, especially if the tourism destination is located in a developing country. This situation has increased the needs of an alternative way to develop tourism sectors, a type of development that will avoid tourism from destroying the 
environment, society and culture. Thus, it comes in the form of sustainable tourism.

It has been described that the world tourism stakeholders are embracing this concept and has taken it seriously. The evidence on events, researches and publications has proven the importance of sustainable tourism. However, the road to apply the concept is a long and winding road because it requires the correct understanding on the concept as well as the participations of various stakeholders.

The main question remains, will the application of the concept bring benefits to the destination and the stakeholders? Then, it also important to make this concept tangible to the stakeholders so they can be convinced to participate and see the benefits from it. For tourism destination the important question is whether the tourist be a loyal customer to the destination because of the application of sustainable tourism development?

The benefits of sustainable tourism development can be seen by its description as the kind of development that meets the need of the present without neglecting the needs of the future generation. Through sustainable tourism destination, attention on environment and socio-cultural conservation are given and integrated in the planning. However, for some stakeholders these benefits seem to be too long to take place and they need a more tangible program and benefits. To address the needs some efforts have been taken to conceptualize, measure and standardize sustainable tourism practices through certification program. The implementation of sustainable tourism certification can be considered as a way to promote the practice of sustainable tourism as well as make the concepts become visible in the real practice.

Certification defined as a set of procedures that audits and gives written assurance that a facility, product, process, service or management system meets specific standards or sustainability (Honey, 2002:4). After a certain entities is certified, it will awarded with a logo, seal or any other indicators that will show that the system of the certified entities has meet specific standards of sustainability.

From the marketing point of view, a logo or indicators of certification can be used as a promotional tool for the related entities. For a destination, a certificate of sustainable tourism development may help them in developing their destination branding. This can be very powerful since the awareness of the ecofriendly and sustainable acts have risen in many societies. Many tourists might come from those societies and the certification may influence their decision in choosing which destination to visit. In this case, the image of a destination that had applied the sustainable tourism principles is important.

Regarding the question whether a certification can result to destination loyalty, the statement from Kandampully \& Suhartanto (2000) may be a stand point. They found that customer satisfaction and image towards the service provider have an impact on the loyalty. This is align with the certification program that gives written assurance that a facility, product, process, service or management system meets specific standards or sustainability. The facility, product, process, service or management system in a tourism destination that meets specific standards of sustainability can result on tourist satisfaction on the destination. Not only that, it will also construct a good image on the destination. Thus, these two will affect the loyalty of the tourist on the destination.

However, it should take into our attention that the certification should not be the final objective of a destination in applying sustainable tourism. It is a tool to help the destination to translate the concept into practice so they can have guidelines on what should or should not do, and of course it can help all of the stakeholders to change the way their attitude and behavior towards tourism development.

In order to make the description clearer, the relationship between sustainable tourism certification and destination loyalty can be described as follows:

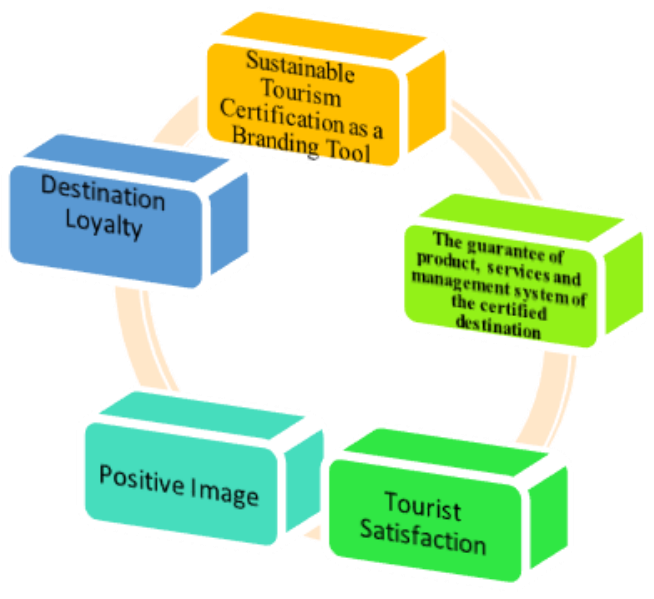

Fig. 2. The Relationship of Sustainable Tourism Certification and Destination Loyalty. Source: Conceptual Review (2016)

The conclusion of this review is that certification of sustainable tourism development on a destination can result on destination loyalty as far as the accountability of the destination in turning the certification standards tangible to the tourists and create positive experience during their stay. The positive experience may enhance the positive image of the destination in their minds and finally resulted on destination loyalty.

\section{REFERENCE}

Creswell, John W. (2009). Research Design: Qualitative, Quantitative, and Mixed Methods Approaches 3rd Edition, USA, SAGE Publisher.

Danim, S. (2002). Being a qualitative researcher. Faithful Reader. Bandung. Free discussion. (N.d.) Retrieved March 24, 2013, from http://id.shvoong.com/writingand- speaking / presenting / 2061554-sense-income /

Hayes, D.K. and Dopson, L.R. (2011). Food and beverage cost control: Fifth edition. New York: John Wiley \& Sons, Inc.

Indonesia Institute of Accountants, (2010). Statement of Financial Accounting Standards / IAS 23. Retrieved March 26, 2013 from www.iaiglobal.or.id

Ivanov, Stanislav H, (2014). Hotel Revenue Management: From Theory to Practice, Edition: 1, Publisher: Zangador, Varna University of Management. 
Kimes, S.E. (1994), Perceived fairness of yield management, the Cornell Hotel and Restaurant Admnistration Quarterly, 29 (1), 22-29.

Kimes, S.E., Chase, R.B. (1998), The strategic evers of yield management, Journal of Service Research, 1(2), pp. 156-66.

Kimes, S.E., Chase, R.B., Choi, S., Lee, P.Y. \& Ngonzi, E.N. (1998). Hotel revenue management: Applying yield management to the hotel industry. Cornell Hotel and Restaurant Administration Quarterly, June 1998; 39.3 Retrieved March 23, 2013, from ABI / INFORM Global (Proquest) database.

Kimes, S.E. (1999), Implementing restaurant revenue management: A five-step approach.

Cornell Hotel and Restaurant Administration Retrieved March 25, 2013 from http://yieldmix.com/restaurant_revenue.pdf

Kimes, S.E., Wirtz, J. \& Noone, B.M. (2002). How long should take dinner? Journal of Revenue and Pricing Management, 4 (1), 220-233.

Kimes, S.E. (2004), Restaurant revenue management: Implementation at Chevys arrowhead, Cornell Hotel and Restaurant Admnistration Quarterly, 45 (1), 52-67.

Kotler, P. (1991). Marketing management: analysis, planning, implementation and control. Prentice Hall Inc., New Jersey.

Miller, J.E., Hayes, D.K. and Dopson, L.R. (2002). Food and beverage costs. New York: John Wiley \& Sons, Inc.

Ninemenier, D. \& J. Hayes, D. K. (2006). Restaurant operations management principles and practices (1st ed.). New Jersey: Pearson Prentice Hall.

Sevinc Gökșen (2011), Implementing of Revenue Management Vrije Universiteit Amsterdam Faculty of Sciences Business Mathematics and Informatics De Boelelaan.

Schmidgall, R.S., Hayes, D.K. and Ninemeier. J.D. (2002). Restaurant financial basics. New Jersey: John Wiley \& Sons, Inc.

Walker, J. R. (2004). Introduction to hospitality management. New Jersey: Pearson Education Inc.

Wyckoff D. D. (2001). New tools for Achieving service quality. Cornell Hotel and Restaurant Administration Quarterly, 44(1), pp. 53-60. 